2016

\title{
Obscuring Gender-Based Violence: Marriage Promotion and Teen Dating Violence Research
}

Carrie N. Baker

Smith College, cbaker@smith.edu

Nan Stein

Wellesley College

Follow this and additional works at: https://scholarworks.smith.edu/swg_facpubs

Part of the Women's Studies Commons

\section{Recommended Citation}

Baker, Carrie N. and Stein, Nan, "Obscuring Gender-Based Violence: Marriage Promotion and Teen Dating Violence Research" (2016). Study of Women and Gender: Faculty Publications, Smith College, Northampton, MA.

https://scholarworks.smith.edu/swg_facpubs/8 


\title{
Obscuring Gender-Based Violence:
}

\section{Marriage Promotion and Teen Dating Violence Research}

\begin{abstract}
:
This article argues that United States public policies have prioritized marriage and healthy relationship promotion over research and education about gendered violence in adult and teen relationships, despite evidence of the prevalence of intimate partner and teen dating violence that disproportionately impacts women and girls. The lack of a gender-based analysis reflects a shift from a feminist framing of violence that focuses on the safety and well-being of women and girls based on an analysis of gender, power, and structural inequalities, toward a conservative focus on individualistic solutions to gendered social problems like poverty and violence.
\end{abstract}

\section{Article}

In a recently-released report, United States Strategy to Prevent and Respond to GenderBased Violence (2012), the United States Agency for International Development (USAID) asserts that women and girls around the world are most at risk and affected by gender-based violence, which occurs in many forms and throughout the life cycle. The report declares that gender-based violence is "rooted in structural inequalities between men and women and is characterized by the use and abuse of physical, emotional, or financial power and control" (2012, 6). Despite this position, United States domestic policies do not always account for the impact of gender on violence. On the one hand, the Violence Against Women Act (VAWA), adopted in 
1994 and reauthorized three times, in 2000, 2005 and 2013, has provided funding for investigation and prosecution of gender-based violence, as well as victim services, and has created new federal crimes involving interstate violence against women. ${ }^{1}$ On the other hand, the United States has enacted and implemented domestic policies that do not adequately attend to gender-based violence. In fact, the United States often takes an individualistic approach to social problems that ignores the role of systemic/structural inequalities based on gender, race and class that contribute to violence.

This individualistic approach has manifested in at least two ways in public policy. First, federal welfare policy, based on the assumption that marriage is a solution to poverty, funds healthy marriage and relationship education programs directed toward adults and youth that focus on individual decision making within relationships without adequate attention to the systemic inequalities related to gender and race that create power imbalances and contribute to poverty and violence in relationships. Second, much federally-funded teen dating violence research and educational materials analyze and present violence as a gender neutral phenomenon without attending to the ways that interpersonal and structural inequalities based on gender, race and class influence manifestations of violence (for example, exacerbating violence against poor women of color). These two trends have combined with the recent shift in public health from an emphasis on disease prevention to one on health promotion to produce a healthy relationship approach to teen dating violence education (Centers for Disease Control and Prevention 2012b) that neglects to incorporate a gender analysis. Based on research that ignores or downplays the gendered causes and impacts of violence, healthy relationship education often does not adequately address gendered violence. 
This article examines federal healthy marriage and relationship promotion programs and teen dating violence research and education in historical context. First, the article examines how “family values" conservatives promoting marriage as a solution to poverty have influenced public policy toward allocating significant federal money to develop and teach healthy marriage and relationship education programs that pay little attention to violence against women and girls in domestic and dating relationships. Then, the article will examine the shift in federally-funded teen dating violence research and education away from a gender-sensitive framework that grew out of a feminist analysis initially provided by the United States grassroots domestic and sexual violence movements (Schechter 1982; Merry 2009; Rambo 2009) toward a gender-neutral framework - that males and females engage in mutual, reciprocal and equivalent violence (Offenbauer \& Buchalter, 2011; Straus 2011; 2008; 2007; 2005; Gelles 1997). While these trends are not directly related, the government's funding of marriage and healthy relationship promotion and teen dating violence research that lacks a gendered analysis are two examples of the way that some U.S. public policies are failing to attend adequately to gendered violence. In fact, government priorities for public policy, if measured by the amount of money allocated, has prioritized marriage and healthy relationship promotion over competitive and scientific research about gendered violence in relationships, despite evidence of the prevalence of domestic and dating violence that disproportionately impacts women and girls (Black, Basile, Breiding, Smith, Walters, Merrick, Chen, and Stevens 2011). These developments reflect a shift from a feminist focus on the safety and well-being of women and girls based on an analysis of gender, power, and structural inequalities, toward a conservative focus on individualistic solutions to social problems like poverty and violence through marriage promotion, the elevation of the heteronormative, patriarchal family, and the obfuscation of gendered violence in teen dating 
relationships. The article concludes with a call for the re-incorporation of a gender analysis into public policy, research, and education relating to violence that would align United States' domestic policy with its foreign policy and mitigate against the dominant individualistic approach to social problems like poverty and violence, an approach that obscures systemic/structural inequalities based on gender, race and class that contribute to these problems. Federal Marriage Promotion Policy

Marriage promotion first appeared in United States public policy as part of welfare reform in the mid-1990s with The Personal Responsibility and Work Opportunity Reconciliation Act of 1996 (PRWORA), which created Temporary Assistance to Needy Families (TANF) to replace Aid to Families with Dependent Children (AFDC). Passed by a Republican Congress and signed by Democratic President Bill Clinton, the Act placed severe limitations on access to welfare, including a five-year lifetime cutoff, a family cap denying benefits to children born to mothers already on welfare, and stringent work requirements. The Act condemned single-mother families, teen pregnancy and out-of-wedlock births, and promoted marriage, two-parent families and "responsible fatherhood and motherhood" as solutions to poverty and "dependency." Congress stated in the first three findings of the Act: “(1) Marriage is the foundation of a successful society; (2) Marriage is an essential institution of a successful society which promotes the interests of children; (3) Promotion of responsible fatherhood and motherhood is integral to successful child rearing and the well-being of children." Marriage was framed as a core national value, a key to success, and the solution to a range of social problems. ${ }^{2}$

PRWORA allowed states to use TANF money for marriage promotion, but it wasn't until George W. Bush became President in 2000 and made marriage promotion an administration priority that federal money flowed directly to marriage promotion activities in 2001. Around the 
same time, Bush implemented a two billion dollar "Charitable Choice" program that allowed faith-based organizations to receive federal funds with few restrictions, so this money could go directly to religious organizations (Hardisty 2008a). States began to implement a range of initiatives to promote marriage, including restrictions on divorce, marriage education programs, and incentives for marriage (Gardiner et al. 2002). The reauthorization of TANF, the Personal Responsibility, Work and Family Promotion Act of 2003, put an even greater emphasis on marriage by stating that a central purpose of the Act was to "encourage the formation and maintenance of healthy 2-parent married families, and encourage responsible fatherhood.” In 2005, Congress specifically allocated money to marriage promotion education and responsible fatherhood initiatives. The Deficit Reduction Act of 2005 (DRA) allocated \$150 million per year over five years for healthy marriage promotion and responsible fatherhood programs. These grants were made available to state and local governments, nonprofit and forprofit organizations, and faith-based organizations, and could be used to promote healthy marriage and "responsible fatherhood" through public advertising campaigns, marriage education for non-married expectant parents, premarital education for engaged couples, marriage enhancement and marriage skills training programs for married couples, marriage mentoring programs, divorce reduction programs, and marriage and relationship education in high schools. The DRA did not require programs funded by these grants to be research-based nor did it require any assessment of their effectiveness (Deficit Reduction Act of 2005, § 7103). The Claims Resolution Act of 2010 and the Middle Class Tax Relief and Job Creation Act of 2012 have continued funding for marriage promotion and responsible fatherhood initiatives.

To run the government's marriage promotion and responsible fatherhood programs, George W. Bush appointed Wisconsin welfare reformer Tommy Thompson to be the Secretary 
of the United States Department of Health and Human Services (HHS) and leading father's rights activist Wade Horn to be the Assistant Secretary for Children and Families at HHS. Thompson had created Wisconsin's "Bridefare," a program that offered an increase in cash welfare benefits to teenage welfare recipients if they married. In his role as Assistant Secretary, Horn was responsible for the government's Healthy Marriage and Fatherhood Initiatives. Before being appointed to HHS, Horn had served as president of the National Fatherhood Initiative and, in the 1980s, was an affiliate of the Hudson Institute, a conservative think tank (Hudson Institute $1999,47)$. In addition to being a strong advocate of marriage promotion as the solution to poverty, he was also a strong advocate of abstinence-based sex education. At HHS, Horn was in charge of distributing millions of dollars of federal money for marriage promotion and responsible fatherhood programs as well as for abstinence-based sex education programs. Marriage promotion programs were targeted to low-income people and people of color, but TANF funds were allowed for marriage promotion activities directed toward the middle-class as well. A significant percentage of the marriage promotion money has been directed toward marriage education for teens (HHS 2012, 3).

Leaders in the domestic violence movement and feminist scholars have critiqued marriage promotion initiatives for paying insufficient attention to domestic violence (Lyon and Menard 2008; 2006; Fineman, Mink and Smith 2003, 126; VAWnet.org 2011). Beth Catlett and Julie Artis (2004) argue that marriage promotion advocates minimize the role of domestic violence in marriage and largely ignore or misrepresent the research on the issue. Contrary to the bulk of social scientific data, marriage promotion advocates claim that marriage is a uniquely safe place for women and that domestic violence is not a pressing concern for young, lowincome women and men (Catlett and Artis 2004). Yet research has shown that "poverty and 
domestic violence are interwoven" (Menard and Williams 2006, 7). Domestic violence is often a factor in divorce, and economic deprivation can impede women from escaping violent relationships (Catlett and Artis 2004, 1237, 1240). While TANF's Family Violence Option allows states to waive some TANF requirements in the interest of safety, a recent study by the National Law Center on Homelessness and Poverty (2009) argues that poor state and local implementation of this waiver has meant that many intimate partner violence survivors have not had access to support. Furthermore, studies show that over half of women receiving welfare report having experienced physical abuse by an intimate partner at some point during their adult lives, 9 to $23 \%$ report abuse in a current relationship (Lyon 2002), and almost 25\% have experienced domestic violence in the year before the study was done (Tolman and Rosen 2001). Stigmatizing single parents and divorce, or making divorce more difficult to obtain, both of which have been part of the marriage promotion agenda, make it more difficult for women to leave abusive partners (Menard and Williams 2006, 7-8). Furthermore, diverting resources away from welfare and into marriage promotion, or conditioning government benefits or services on attending marriage education programs, may compromise women's ability to leave abusive relationships by placing pressure on them to stay in those relationships or to marry abusive partners, thereby endangering women and their children.

Marriage promotion policies do not entirely ignore domestic violence, but they often have not adequately addressed it. The Personal Responsibility, Work, and Family Promotion Act of 2003 requires grant recipients to consult with domestic violence experts or coalitions as part of program development. However, critics say these policies do not do enough to ensure the safety of women and their children (Catlett and Artis 2004, 1235-1236). Concerns about the failure to address domestic violence led to a May 2006 conference, "Building Bridges: Marriage, 
Fatherhood and Domestic Violence," sponsored by the Center for Law and Social Policy and the National Conference for State Legislatures (Ooms, Boggess, Menard, Myrick, Roberts, Tweedie, and Wilson 2006) and, in 2008, a Congressional briefing on domestic violence and healthy marriage programs (VAWnet.org 2008). These efforts led more marriage promotion fund recipients to work with local domestic violence service agencies to develop enrollment screening tools and response protocols. The attempt to develop productive relationships between marriage promotion programs and domestic violence agencies, however, remains challenging (Lyons and Menard 2008). In her in-depth study of marriage promotion education in Oklahoma, Melanie Heath found that domestic violence was "unevenly addressed" in workshops for TANF clients (Heath 2012, 108). A recent study of fatherhood programs revealed that these programs were not adequately addressing domestic violence, despite ACF requirements (Roulet 2009, 30-31; Hawkins and Ooms 2012, 11).

Marriage promotion campaigns in the United States have also been critiqued for teaching patriarchal and homophobic norms that could perpetuate gendered violence. Jean Hardisty argues that marriage promotion programs often reflect racial, ethnic and gender stereotypes (Hardisty 2008a). Sex-stereotyped programming in an Allentown, Pennsylvania marriage education course resulted in a complaint challenging the program for sex discrimination under Title IX, the federal law prohibiting sex discrimination in educational programs receiving federal funds. The program offered job training and placement services to fathers but not to mothers, and set a goal of $90 \%$ of participating fathers finding employment but no such goal was set for mothers (NOW Legal Defense and Education Fund 2004). Based on her Oklahoma study of marriage promotion, Melanie Heath argues that the marriage promotion movement seeks to "stabilize the norm of the white, middle-class, heterosexual family" through state-sponsored marriage workshops that teach 
"gender hierarchy to rehearse an implicit ideology of marital heterosexuality" (Heath 2009, 27).

Gender differences were stressed in marriage workshops, which taught "cultural ideas of men as rational (strong) and women as emotional (weak)" (Heath 2009, 27, 44). Research has linked male violence against females to males' greater support for traditional norms (Reed, Silverman, Raj, Decker and Miller 2011, 234); therefore programs that teach gender hierarchy may reinforce men's sense of entitlement to control women. By ignoring domestic violence and teaching gender hierarchy, marriage promotion education becomes fertile ground for the perpetuation of gendered violence because "gender norms that promote male dominance and control...ultimately serve as the foundation of gender-based violence" (Reed, Raj, Miller and Silverman 2010, 351). Kaaryn Gustafson, of University of Connecticut Law School, argues that marriage has become a powerful "symbol representing anxieties about changing patterns of living arrangements and child bearing, about sexuality and the state's role in policing it, and about the volatile notions of masculinity and femininity" (Gustafson 2009, 272). She argues that marriage promotion and fatherhood movements undermine gender and racial equality in the home and in the labor market, reinforce economic inequality among families, and perpetuate discrimination against non-marital and non-heterosexual families. If poverty is a risk factor for domestic violence, then redirecting welfare money that could help lift women out of poverty into programs that push women into marriage and reinforce gender hierarchy could place poor women in further danger.

The healthy marriage and relationship promotion campaign has been directed not only at adults, but at teens as well, and some researchers and feminist activists have expressed concerns that these curricula efforts, especially embodied in the curriculum products that have been created with federal funding, are similarly obscuring gendered violence and reinforcing gendered stereotypes (Heath 2012, 123-150). A significant portion of the money allocated to 
marriage promotion goes to organizations that develop and implement relationship curricula in secondary schools. In 2006, Administration for Children and Families of the Department of Health and Human Services (HHS) awarded fifteen out of a total of forty-four grants in the range of $\$ 450,000$ to $\$ 550,000$ annually to organizations specifically focused on high school-age youth (the remaining 29 are directed toward adults) (HHS 2012, 3). In a recent HHS report reviewing these programs, only four of the fifteen programs mention dating violence in the description of their activities and only a few included dating violence in their program evaluation (HHS 2012, 22). The 2012 HHS report briefly addresses dating violence, but characterizes it as mutual. For example, citing the Centers for Disease Control and Prevention (CDC) Youth Risk study, the report states that boys and girls report similar levels of physical dating violence $(11.9 \%$ and $10.8 \%$ respectively), without noting the significant differential impact of the violence (HHS 2012, 7). The report mentions the occurrence of sexual violence, but does not discuss prevalence or impact at all. While an in-depth study of these curricula is beyond the scope of this article, there are indications that some of these curricula, similar to the adult marriage promotion programs, reinforce gender stereotypes. The names of some of the high school healthy marriage and relationship curricula themselves reflect gender stereotyping, like "Vessels of Honor and Capturing Vision" or "Diamond Girl Leadership and Best Men Leadership" (HHS 2012, 54). Melanie Heath's Oklahoma study found similar patterns of traditionalism, heterosexism and inadequate discussion of dating violence in marriage promotion curricula used in Oklahoma middle and high schools as she did in the adult curricula (Heath 2012, 123-150). The lack of attention to gendered violence in federally-funded healthy marriage and relationship education programs is a prime example of the obscuring of gender-based violence in United States domestic policy. 
Gender hierarchy and inadequate attention to gendered violence in marriage promotion curricula is not surprising given the roots of the marriage promotion movement in conservative Christian and fatherhood groups. In the 1990s, concerned about high rates of divorce and single motherhood and an increasing number of gay and lesbian families, conservative organizations like the Heritage Foundation and the Christian Coalition turned to promoting "family values" —a traditional heterosexual nuclear family model. According to Hardisty, marriage promotion is “driven by conservative ideology, a backlash against the social reforms of the 1970s and 1980s, and a commitment by the Republican Party to 'restore' the idealized 'father knows best' family model of the 1950s" (Hardisty 2008a). These efforts were supported by conservative scholars like Maggie Gallagher, Allan C. Carlson, Robert Rector, Lawrence Mead, and Judith Wallerstein, who write in favor of marriage as a cure for poverty (Hardisty 2009b, 2).

Marriage promotion also grew out of the fatherhood movement, which has diverse ideologies and agendas, including militant "father's rights" groups, more moderate center/right groups, and liberal "profeminist fatherhood" groups. The father's rights groups are composed of fathers angry about public policy and court decisions relating to divorce, child custody and child support, and they often claim that women make false allegations of battering or incest against them to gain custody of children (Hardisty 2008a; Dragiewicz 2012, 15-18). The more moderate center/right fatherhood movement includes groups like Promise Keepers and The Fatherhood Initiative (which, as noted above, was led by Wade Horn in the 1990s). The rightist sector of the movement is based in conservative Christian theological principles that explicitly advocate patriarchy, promoting men as the God-given leaders of families, and instructing women to be obedient wives (Hardisty 2008a). Through marriage promotion and fatherhood initiatives 
funding, these anti-feminist organizations have obtained federal money to promote heterosexual marriage and the centrality of men and fathers to functional families (Hardisty 2008a).

In addition to bolstering the patriarchal family through marriage promotion, anti-feminist father's rights groups have acted in more direct ways to obscure gendered violence in intimate relationships. Father's rights activists in Minnesota, for example, sued the state in Booth v. Hvass (2002), claiming that the state's domestic violence laws were sex discriminatory because they funded battered women's shelters that advocated on behalf of and served women; this is one of many such lawsuits across the country (Dragiewicz 2012, 1, 81-102). These anti-feminist men's groups use the "language of gender neutrality to attack programs created to ameliorate the outcomes of gendered inequality" and they "seek to reassert the patriarchal prerogative to define violence and delimit responses to it" (Dragiewicz 2011, 14-15). They advocate a "new patriarchy" that seeks to "stabilize the now unstable notions of masculinity and empower men" (Gustafson 2009, 281). The core father's rights claim that domestic violence is sex-symmetrical has significantly influenced mainstream conversations and politics (Dragiewicz 2011, 18). A study of conservative political and men's magazines like The National Review, The New Republic and Penthouse, revealed that discussion of domestic violence obscured men's perpetration of violence while placing the burden of responsibility for that violence on women (Berns 2001). Dragiewicz argues, "these discourses proclaiming sex symmetry in violence against intimates serve to reproduce the conditions that enable violence by silencing those most adversely affected, obscuring structural contributing factors, and echoing abusers" (Dragiewicz $2011,7)$.

The predominantly white fatherhood movement has targeted communities of color with marriage promotion events and materials, like "Black Marriage Day," put on in seventy cities by 
the Wedding Bliss Foundation with direct assistance from HHS, and publications like Proud Poppa, which "promote the nuclear family model that emphasizes the father as a the principal determinant of the success of children and the family" (Hardisty 2008a). ${ }^{3}$ According to Hardisty (2008a), through gaining access and building trust using federal money, the white fatherhood movement can "recruit men and women in low-income communities of color to collaborate in the Right's 'cure' for their poverty.” By attributing poverty to individual pathology—poor interpersonal skills and bad decisions-making that can be "cured" through marriage education or flawed culture - supporters of marriage promotion can ignore the structural factors contributing to poverty, such as unemployment, race and sex discrimination in employment, and high incarceration rates of poor men of color, thereby obviating the need for public policies to address these systemic conditions. Gustafson argues that marriage promotion "distracts attention from the larger issue of poverty," "diverts government resources from programs that serve low-income families," and “is part of a conservative effort to privatize risk" (Gustafson 2009, 304).

Marriage as a cure for poverty, in fact, is not supported by social science evidence and relies on logical fallacies, like using the correlation of two variables to prove causality, the single causation fallacy, anecdotal evidence, and the denial of racism's role in creating and maintaining poverty (Hardisty 2008b, 2-4). Barbara Ehrenreich estimates that, at current wage rates, lowincome women would need to have approximately 2.3 husbands to lift them out of poverty (Olsen 2005). According to Heath, anxieties around race manifest in the racial comparisons that are a common theme in marriage promotion discourse, expressed as concern that "the once isolated breakup of Black families is now spreading to white ones" (Heath 2009, 34). Despite the fact that funding comes through TANF, which focuses attention on single-mother families “coded as women of color and their children," Heath found that marriage promotion services in 
Oklahoma were offered predominately to white, middle-class families, presumably to stop the "spread" of single parenthood (Heath 2009, 43). So meager TANF funds are redirected away from helping those in poverty to bolster marriage among white, middle-class people. In light of the conservative roots of marriage promotion in the United States, it is not surprising that these programs have contributed toward obscuring gendered violence in adult and teen relationships by promoting traditional ideas of family as well as traditional gender and race hierarchies.

\section{The Erasure of Gender in Teen Dating Violence Research and Education}

The lack of gender-based analysis exists not only in marriage promotion activities, but also in federally-funded teen dating violence research and education. Contrary to the USAID report framing violence against women and girls as gendered (USAID 2012), teen dating violence research in the United States rarely raises or examines how gender influences manifestations of violence (for examples of research that lacks a gendered analysis, see Straus 2005, 2007, 2008, 2011; Chiodo, Crooks, Wolfe, McIssac, Hugher \& Jaffee 2012; O’Leary \& Slep, 2012; Tharp 2012). Critics have argued that research on teen dating violence has evolved over several decades toward being framed as gender neutral (Reed et al. 2010; Kurz 1997, 448). Comparing research from 1998 and 2008, Reed et al. found a shift towards framing teen dating violence as "mutual aggression" or "reciprocal violence." There is very little teen dating violence research that uses an intersectional analysis of gender, race, and class. These parallel phenomena-marriage promotion that ignores domestic violence and federally-funded domestic and dating violence research that lacks a gendered analysis-indicate how some federal public policies are manifesting a trend toward decreased gender awareness and analysis, reflecting antifeminist and/or postfeminist currents in public policy. 
Educational materials about interpersonal violence in K-12 schools have also undergone this shift toward a gender-neutral framing of teen dating violence. The transition is apparent when comparing educational materials on teen dating violence produced at the beginning of the twenty-first century by the National Youth Violence Prevention Resource Center (2001) and the Centers for Disease Control and Prevention (CDC) (2002) with more recent versions of CDC fact sheets on teen dating violence (CDC 2012a; 2012b; 2012c) and with recent discussion of the forthcoming CDC educational program, Dating Matters $^{\text {TM }}$ (Tharp 2012). Gender neutrality has often been seen as expedient and palatable and has thus found its way into relationship violence prevention education in schools as implemented by staff from sexual assault and domestic violence agencies who use the degendered framework of "bullying" prevention or the CDC "healthy relationships" framework (Stein and Hong 2012; Tharp 2012). The preponderance of male perpetration of violence in dating relationships as confirmed by decades of surveys and crime reports (Black et al. 2011; Catalano 2007; Hickman et al. 2004; Jouriles et al. 2009) is obscured when teen dating violence is presented as mutually created and sustained, and experienced equivalently by males and females (Offenbauer \& Buchalter, 2011; CDC 2012a; 2012b; 2012c; Tharp 2012).

The gender-neutral framing of teen dating violence research has resulted, at least in part, from the way the problem is measured, first using the conflict tactics scale and more recently, relying on the one question from the Youth Risk Behavior Surveillance Survey on teen dating violence. The conflict tactics scale, developed by Straus, Hamby, Boney-McCoy, and Sugerman ([1979] 1996), is fraught with methodological and definitional problems that skew the data and the problem (DeKeseredy 2000; DeKeseredy and Schartz 1998; 2001; Morse 1995). This measure, also referred to as the "acts scale" (Straus et al. [1979], 1996), counts and compares the 
number of hits or slaps. Some researchers have expressed concerns with the way teen dating violence studies have relied primarily on "act scales" without looking at the context of violence in the lives of girls and young women (Mulford and Blachman-Demner 2013, 764; DeKeseredy 2000; DeKeseredy and Schartz 1998; 2001; Morse 1995). This degendered method of determining teen dating violence obscures two salient measures: the response to the threat of violence and the severity of the consequences suffered as a result of violence. These gendered dimensions of violence reveal the significant and disproportionate role of dating violence in the lives of girls and young women in a way that merely counting hits cannot.

In addition to the reliance on "acts scales" that provide the basis for the mutual aggression framework, reliance on the teen dating violence data gathered by the CDC from the Youth Risk Behavior Surveillance Survey (YRBS Survey) tends to produce prevalence rates that are misleading by reinforcing the notion of equivalent victimization between boys and girls. This survey is administered in nearly every state to a representative sample of high school students with varying state sample sizes; in addition there is one national survey with approximately 10,000 respondents. Amid multiple questions about smoking, drinking, driving, food consumption, and drug use, there is only one question that asks about dating relationship violence: "During the past 12 months, did your boyfriend or girlfriend ever hit, slap, or physically hurt you on purpose?" Results compiled over a ten year period (1999-2009) found essentially no gender differences in victimization rates, with equivalent rates of boys and girls having reported that they had been hit, slapped, or physically hurt on purpose by their boyfriend or girlfriend in the past year.

While such findings may suggest gender symmetry in teen dating violence, researchers have critiqued reliance on the YRBS Survey findings for making such conclusions. Rothman 
(2012) has identified several methodological limitations of the YRBS Survey question on teen dating violence, such as the time frame (past year versus ever), the inclusion of only physical violence (no sexual or psychological violence), and restricted relationship status ("boyfriend/girlfriend" rather than just casual dating). Rothman has pointed towards the Massachusetts state version of this question, which is more nuanced than the national YRBS Survey question: "Have you ever been hurt physically by a date or someone you were going out with? (Include being hurt by being shoved, slapped, hit, or forced into any sexual activity?) (Massachusetts Department of Education 2011, 5). Data drawn from the Massachusetts version of the question indicate that nearly twice as many girls than boys report experience of teen dating violence victimization. When the question is asked in a way that allows for more sensitivity to gendered differences, gender disparity emerges. This gender difference in terms of victimization supports the use of gender-sensitive framework for understanding teen dating violence.

Other studies that have included a more gendered analysis explain the seemingly reciprocal or equivalent rates of violence. Hamby, Finklehor, and Turner (2012), in an article that summarizes their research on teen dating violence and co-occurrence with other victimization (part of their National Survey of Children's Exposure to Violence, known as NatSCEV) found that among the respondents to a telephone survey (1680 youth aged 12-17), males reported higher rates than females for physical teen dating violence (TDV) victimization. Yet, as the researchers dug deeper into this finding, they found that "three times as many female physical TDV victims as male TDV victims reported an injury and females were markedly more afraid" (Hamby et al. 2012, 10). The finding of more fear and intimidation experienced by girls is consistent with earlier gender-based teen dating violence research. Molidor and Tolman (1998) found that when males experienced violence, more than half said they reacted by laughing and 
nearly one third ignored it, while among girls, $40 \%$ cried and $36 \%$ defended themselves. Some research suggests that boys tend to perpetrate more severe physical violence-e.g., involving weapons and punching - and more sexual violence than girls. On the other hand, girls may commit minor to moderate abusive acts (e.g., scratching, slapping, and throwing objects), may engage in more verbal aggression, and may suffer more psychological and sexual victimization than boys (Foshee, Benefield, Suchindran, Ennett, Bauman, Karriker-Jaffe, Reyes, and Mathias 2009; Sears, Byers, Whelan, and Saint-Pierre 2006). Closer attention to the gendered responses and consequences of teen dating violence illuminates that although both parties in the relationship may be violent, the term "mutual" does not accurately describe the dynamics of violence.

As surveys and research have indicated, girls experience negative consequences of dating violence that are more severe and place them at higher risk for various harmful physical and mental outcomes. For example, girls who experience dating violence are four to six times more likely to become pregnant than their peers (Silverman, Raj, Mucci, and Hathaway 2001; Silverman, Raj, and Clements 2004). They are also more likely to have suicidal thoughts and attempts, eating disorders, lower self-esteem, and poorer emotional well-being (Silverman et al. 2001; 2004; Ackard and Neumark-Sztainer 2002). By paying attention to gender-specific consequences and risk factors, tailored prevention strategies can be created to help reduce victimization and perpetration.

The causes of violence are also gendered. Reed et al.'s research (2011) on male perpetration of teen dating violence in urban neighborhoods found that "TDV perpetration is linked to boys' greater support of traditional gender norms, particularly norms related to relationships and sex" (234). In contrast with recent studies on the prevalence of mutual 
aggression in teen dating violence, the Reed et al. (2011) study reveals that boys' adherence to traditional gender norms contributes toward increased risk of boys' perpetration of violence against girls. Similarly, Tolman, Spencer, Rosen-Reynoso, and Porche argue, based on qualitative research involving adolescent boys and girls, that "conventional norms of heterosexual relationship dynamics produce and require male dominance and female submission," which they argue contribute to high rates of teen dating violence (Tolman et al. 2003, 161). These findings support the need for a gendered approach within prevention programming, such as tailoring components by gender, focusing on social norms associated with boys' attitudes toward gender, and exploring attitudes around gender inequities. This connection between support for traditional gender norms and teen dating violence perpetration also suggests that healthy marriage and relationship education that teaches traditional gender norms might actually contribute to violence against girls and young women.

Research suggests that gendered prevention programming should start early, certainly by middle school (Reed et al., 2011; Taylor, Stein and Burden, 2010a; 2010 b; Taylor, Stein, Mumford and Woods, 2013). Intervention during pre-adolescence is advisable because there is evidence from the National Intimate Partner and Sexual Violence Survey that many adults who experience intimate partner violence (IPV) have a history of teen dating violence (Black et al. 2011). This survey, which is an on-going, nationally representative telephone survey that collects information from adults on sexual violence, stalking and intimate partner violence in the United States and which has a total sample size of 16,507 (9086 women and 7421 men), found that when adult victims were asked to reflect back on their first experience of violence, $69 \%$ of female victims and $53 \%$ of male victims of rape, physical violence, and/or stalking by an intimate partner reported that they had experienced intimate partner violence for the first time 
before 25 years of age. Moreover, $42.2 \%$ of female victims of rape experienced their first completed rape before the age of 18 years $(12 \%$ reported that the rape occurred before age 10 years and $30 \%$ between ages 11 to 17 ) (Black et al., 2011). While those who experienced violence during early years do not always experience victimization again, the connection between experiencing intimate partner violence at a younger age and being at risk for it as an adult is strong and warrants further research. It also indicates the need for both teen dating violence and adult intimate partner violence prevention strategies to take on a life-course perspective, which means considering the interconnections between victimization and perpetration of violence during adolescence and adulthood.

Moving away from a gender-based framework has serious implications for teen dating violence programs, policies, and education. Since prevention strategies are prioritized and shaped by the framework used to understand the source and expression of violence, the framework determines what intervention strategies are employed. Thus researchers who promote the notion of "reciprocal violence" or gender symmetry in teen dating violence argue that resources should be directed toward preventing female partner perpetration and male victimization (Reed et al, 2010, 349-350). Yet there is a need to "distinguish IPV that threatens the lives and well-being of populations of women and girls as a result of gender-power imbalances from interpersonal violence that female partners may use against male partners" (Reed et al. 2011, 351). The erasure of gender in understanding teen dating violence may also negatively influence public health interventions. Approaches to preventing teen dating violence that shift from a gendered analysis to one of mutual aggression run the risk of critically misplacing resources for intervention and education. 
Not surprisingly in light of the research framing teen dating violence as gender-neutral, CDC-written and funded educational materials on teen dating violence uses the mutual aggression approach to teen dating violence. For example, a CDC fact sheet titled “Understanding Teen Dating Violence” (2012a), the CDC's publication "Dating Matters ${ }^{\mathrm{TM}}$ : Strategies to Promote Healthy Teen Relationships," and the CDC's teen dating violence website (2012c) never mention differential impacts of violence on girls and boys. They do mention that a higher percentage of women than men $(22.4 \%$ and $15 \%)$ first experience some form of partner violence between 11 and 17 years of age, but in lists of risk factors, they do not mention gender or gender-stereotyped attitudes. These publications fastidiously use "his or her," "him/her," "he or she," "girlfriend/boyfriend," etc., giving the impression that teens are equally harmed by dating violence.

In another publication, a literature review funded by the Department of Justice of teen dating violence research, a section on gender begins with a discussion of research claiming that females are more likely to inflict abuse than males, but then states that "the majority of violent adolescent relationships involve mutual or reciprocal violence" (Offenhauer and Buckalter 2011, 11). Not until the second paragraph of the section does the review mention that "some research suggests" that boys perpetrate more severe physical violence and more sexual violence, and that girls suffer more "psychological and sexual victimization than males," omitting any mention of girls' non-sexual physical victimization. The publication emphasizes girls as perpetrators by mentioning this research first, then qualifying the reference to research on the severity of boys' violence toward girls, giving the misleading impression that girls' violence is as much or more of a problem than boys' violence. A later section titled "Beliefs and Norms as Risk Factors: Attitudes Regarding Violence and Gender" at first focuses on "beliefs and attitudes tolerant of 
dating violence," which males are more likely to have. Again, not until the second paragraph does the review mention "some evidence" that "holding traditional beliefs about male and female gender roles in relationships is a risk factor for involvement in dating violence" (Offenhauer and Buchalter 2011, 19). The authors explain: "patriarchal gender ideas about males may promote the infliction of abuse and influence the type of abuse used, while sexist stereotypes about females and a female's gender socialization may increase the odds of victimization" (Offenhauer and Buckalter 2011, 19). This confusing sentence describes violence in passive terms and uses language that appears to blame women who are victims of violence, both common techniques used by courts and the media that have the effect of obscuring or minimizing male perpetration and responsibility for violence against women (Bavelas and Coates 2001). The authors then immediately turn to how "a double standard on gender roles" might actually protect women because it can "dampen the proclivity of males to use violence when such a standard leads to condemning a male's resort to violence more harshly than a female's" (Offenhauer and Buckalter 2011, 19). These materials, similar to teen dating violence research, omit an analysis of gender and the systemic inequalities related to gender and race that create power imbalances that contribute to violence in relationships.

\section{Disparity of Resource Allocation}

Federal funding for teen dating violence research is scant in comparison to marriage promotion and relationship education funding. Both are competitive awards, but the requirements for the competitions are vastly different. ${ }^{4}$ In the Deficit Reduction Act of 2005, Congress created two categories of funding for five years - one that focused on marriage promotion, including healthy teen dating relationships, and a second related category that funded responsible fatherhood initiatives. Congress allocated $\$ 150$ million per year for these programs, 
of which up to $\$ 50$ million could go toward responsible fatherhood initiatives. The Claims Resolution Act of 2010 and the Middle Class Tax Relief and Job Creation Act of 2012 continued this funding at the level of $\$ 75$ million for each category, although HHS has in fact distributed approximately $\$ 60$ million in each category the last several years (see grants announced in October of 2011 at http://archive.acf.hhs.gov/news/press/2011/Grantawards2011.html and grants announced in January of 2013 at https://www.acf.hhs.gov/programs/ofa/resource/healthymarriage-grantees). This money has funded "demonstration" projects where evaluation of the effectiveness of these programs was not required by Congress or the Administration for Children and Families in Health and Human Services who administers the program. These programs operate without the scientific rigor normally required of grant recipients (Deficit Reduction Act of 2005, § 7103).

The amount of funding for healthy marriage and relationship promotion was significantly more generous than the combined grant awards offered to teen dating violence researchers who compete for funding awarded by several federal agencies, including the National Institute of Justice (NIJ) of the United States Department of Justice, the National Institutes of Health (NIH), and the $\mathrm{CDC}$, agencies that impose stringent requirements for evaluation for effectiveness and other measures of scientific rigor upon the grant recipients. For example, NIJ appropriated only \$2.5 million for TDV research in 2009, which was divided among several researchers, while most years its funding for external research has been closer to $\$ 1$ million (2008 and 2010). The total NIJ funding for teen dating violence research between 2008 through 2012 was close to \$10 million (NIJ 2011; Mulford and Blachman-Demner 2013, 759). NIH, on the other hand, a much larger federal agency, has provided around $\$ 10$ million over seven years (2005-2012) to research projects on dating violence. ${ }^{5}$ Finally, the CDC has appropriated $\$ 15.5$ million from 2007-2012 
on research. Again, this is highly competitive money, with stringent requirements for peer review, evaluation, efficacy and expectations for publication in peer reviewed journals.

A comparison of federal funding for healthy marriage and relationship promotion programs to the level of funding for teen dating violence research reveals that there is a sizable disparity between these two funding streams - approximately $\$ 60$ million for marriage promotion versus approximately $\$ 6$ million for teen dating violence research and education. This tenfold disparity has contributed toward the obfuscation of violence against women and girls by generously funding marriage promotion programs that have ignored gendered violence while providing only limited funds for teen dating violence research and education, most of which has gone to research lacking a gendered analysis of teen dating violence. Clearly there are limited funds to be devoted to any of these programs so money that goes to fund projects that are not research based means that there will be less funding for those programs that are scientific. With the advent of "sequester," this is all the more the case.

\section{Conclusion}

Marriage promotion and gender-blind teen dating violence research and education have divergent origins but both reinforce the obscuring of gendered violence. Marriage promotion grows out of the conservative "family values" movement in the United States whereas the degendered explanation of teen dating violence has grown out of non-feminist academic research, but both end up obscuring the disproportionate effects of violence against women and girls, thereby reinforcing traditional gendered hierarchies. Conservative advocates of marriage promotion ignore gendered violence in the interest of preserving the patriarchal family; to challenge male violence would challenge male authority in relationships. Some researchers who minimize violence against girls, on the other hand, decontextualize violence and assume that 
gender equity has been achieved. By omitting considerations of power and social context, all violence appears to be equivalent and the differential consequences are minimized or forgotten. So gender parity becomes a framework that obscures the gendered nature of violence. As this paper has argued, these trends toward ignoring gender in public policy grow at least in part from anti-feminist attempts to shore up traditional notions of the family and post-feminist assumptions that sexism no longer exists.

The trends of marriage promotion and gender-blind teen dating violence research and education are similar to other trends in United States society that obscure gendered violence and reinforce traditional gender norms. Examples include the displacement of sexual harassment frameworks with bullying frameworks (Brown, Chesney-Lind, and Stein 2007; Stein 1995; 2003; 2011; Stein and Mennemeier 2011; United States Department of Education Office of Civil Rights, 2010) and abstinence-based sex education, which often teach gender stereotypes about sexuality (United States House of Representatives 2004, 16-18). These developments in education seriously undermine the goal of equality and empowerment of girls. Gender norms that promote male dominance and control of females are the foundation for trivializing or ignoring gender-based violence. Obscuring gender-based violence turns a blind eye not only to the disproportionate effect of violence on women and girls, but also ignores the disproportionate perpetration of violence by males. Because male violence is normalized in American culture (Katz 2006), masculinity is rarely acknowledged, much less analyzed, as a factor in violence (Kimmel 2002; Steinem 1999; Perlstein 1998).

The degendering of public policy, research and education relating to violence in the United States, however, runs counter to the thrust of the United States' recently-released USAID report, which emphasized that women and girls around the world are most at risk and affected by 
gender-based violence and that gender-based violence is "rooted in structural inequalities between men and women and is characterized by the use and abuse of physical, emotional, or financial power and control" (USAID 2012, 6). ${ }^{6}$ Paying attention to gendered violence is important not only internationally, but domestically as well. Therefore, research, education and public policies must pay more attention to the gendered nature of violence, and to the social norms and structural inequalities relating to gender, race and class that contribute to this violence.

\footnotetext{
${ }^{1}$ A third important provision of the original VAWA created a federal civil right to be free from gender-based violence, but this provision was struck down in the 2000 Supreme Court case of United States v. Morrison, which held that Congress lacked jurisdiction to create this remedy because the Court considered violence against women to be a state concern, not a federal concern, a decision that arguably underestimated the scope and impact of violence against women in the United States.

${ }^{2}$ The same year Congress passed the Defense of Marriage Act (1996), defining marriage exclusively to be the union of one man and one woman. Together these laws reflected the conservative influence on definitions of family in federal public policy.

${ }^{3}$ Interestingly, the U.S. Department of Health and Human Services Healthy Marriage Initiative website active through 2012 organized marriage education materials by race, divided as follows: Asian and Pacific Islander, African American, "Hispanic," and American Indian. There was not a page focused on Caucasian Americans. See archived page at file://C:/Users/Carri/Documents/Administration/Inactive\%20Classes/Class\%20Introduction\%20 to\%20SWG/Private\%20Lives\%20Public\%20Policy/ACF\%20Healthy\%20Marriage\%20Initiative $\underline{. h t m}$.
} 
${ }^{4}$ Rape prevention education funding from the CDC, which flows through state public health departments and then on to sexual assault and domestic violence centers, is "entitlement" funding, which is allocated on a per capita basis to the states.

${ }^{5}$ This amount was determined with NIH's Research Portfolio Online Reporting Tools (see RePORTER at http://projectreporter.nih.gov/reporter.cfm) using the term "dating violence" and restricting the search to the agencies that typically fund research in this area: the Eunice Kennedy Shriver National Institute on Child Health and Human Development (NICHD), the National Institute of Mental Health (NIMH), the National Institute on Alcohol Abuse and Alcoholism (NIAAA), and the National Institute of Nursing Research (NINR).

${ }^{6}$ Similarly, Renée Römkens $(2013,195)$ argues that a gender analysis is "under siege" within the Council of Europe. 


\section{References}

Ackard, Diann M., and Diane Neumark-Sztainer. 2002. "Date Violence and Date Rape Among Adolescents: Associations with Disordered Eating Behaviors and Psychological Health.” Child Abuse and Neglect 26: 455-473.

Bavelas, Janet and Linda Coates. 2001. "Is it Sex or Assault: Erotic Versus Violent Language in Sexual Assault Trial Judgment." Journal of Social Distress and the Homeless 10(1): 2940.

Berns, Nancy. 2001. "Degendering the Problem and Gendering the Blame: Political Discourse on Women and Violence." Gender and Society 15: 261-282.

Black, Michele C., Kathleen C. Basile, Matthew J. Breiding, Sharon G. Smith, Mike L. Walters, Melissa T. Merrick, Jieru Chen, and Mark R. Stevens. 2011. The National Intimate Partner and Sexual Violence Survey (NISVS): 2010 Summary Report. Atlanta, GA: National Center for Injury Prevention and Control and the Centers for Disease Control and Prevention.

Booth v. Hvass. 2002.302 F. $3^{\text {rd }} 849$ ( $8^{\text {th }}$ Cir. 2002).

Brown, Lyn M., Meda Chesney-Lind, and Nan Stein. 2007. "Patriarchy Matters: Toward a Gendered Theory of Teen Violence and Victimization.” Violence Against Women 13(12): $1249-1273$.

Catalano, Shannon. 2007. Intimate Partner Violence in the United States. Washington DC: U.S. Department of Justice Bureau of Justice Statistics. http://bjs.ojp.usdoj.gov/content/pub/pdf/ipvus.pdf (May 19, 2013). 
Catlett, Beth Skilken, and Julie E. Artis. 2004. "Critiquing the Case for Marriage Promotion: How the Promarriage Movement Misrepresents Domestic Violence Research.”Violence Against Women 10: 1226-1244.

Centers for Disease Control and Prevention. 2012a. Understanding Teen Dating Violence. Atlanta, GA: Centers for Disease Control and Prevention. http://www.cdc.gov/ViolencePrevention/pdf/TeenDatingViolence2012-a.pdf (May 19, 2013).

Centers for Disease Control and Prevention. 2012b. Dating Matters ${ }^{\mathrm{TM}}$. Strategies to Promote Healthy Teen Relationships. Atlanta, GA: Centers for Disease Control and Prevention. http://www.cdc.gov/violenceprevention/pdf/dm_overview-a.pdf (May 19, 2013).

Centers for Disease Control and Prevention. 2012c. Teen Dating Violence (website). http://www.cdc.gov/violenceprevention/intimatepartnerviolence/teen_dating_violence.ht $\underline{\mathrm{ml}}$ (May 19, 2013).

Centers for Disease Control and Prevention. 2002. Dating Violence. Atlanta, GA: Centers for Disease Control and Prevention.

Chiodo, Debbie, Claire V. Crooks, David A. Wolfe, Caroline McIssac, Ray Hughes, and Peter G. Jaffee. 2012. "Longitudinal Prediction and Concurrent Functioning of Adolescent Girls Demonstrating Various Profiles of Dating Violence and Victimization.” Prevention Science 13(4): 350-359.

Claims Resolution Act. 2010. Statutes at Large. Vol. 124, sec. 3064.

Defense of Marriage Act. 1996. U.S. Code. Vol. 1, sec. 7 and Vol. 28, sec. 1738C.

Deficit Reduction Act of 2005. 2006. Statutes at Large. Vol. 120, sec. 4. 
Dragiewicz, Molly. 2011. Equality With a Vengeance: Men's Rights Groups, Battered Women, and Antifeminist Backlash. Boston, MA: Northeastern University Press.

Fineman, Martha, Gwendolyn Mink, and Anna Marie Smith. 2003. "No Promotion of Marriage in TANF! A Position Paper.” Social Justice 30: 126-134.

Foshee, Vangie A., Thad S. Benefield, Chirayath Suchindran, Susan T. Ennett, Karl E. Bauman, Katherine J. Karriker-Jaffe, Heather L.M. Reyes, and Jasmine Mathias. 2009. “The Development of Four Types of Adolescent Dating Abuse and Selected Demographic Correlates." Journal of Research on Adolescence 19: 380-400.

Gardiner, Karen N., Michael E. Fishman, Plamen Nikolov, Asaph Glosser, and Stephanie Laud. 2002. State Policies to Promote Marriage: Final Report. Washington, DC: United States Department of Health and Human Services.

Gelles, Richard J. 1997. Intimate Violence in Families ( $3^{\text {rd }}$ ed.). Thousand Oaks, CA: Sage Publications.

Gustafson, Kaaryn. 2009. "Breaking Vows: Marriage Promotion, the New Patriarchy, and the Retreat from Egalitarianism." Stanford Journal of Civil Rights \& Civil Liberties 5: 269308.

Hamby, Sherry, David D. Finklehor, and Heather Turner. 2012. “Teen Dating Violence: Cooccurrence with Other Victimizations in the National Survey of Children's Exposure to Violence." Psychology of Violence 2(2): 111-124.

Hardisty, Jean V. 2008a. Pushed to the Alter: The Right Wing Roots of Marriage Promotion. Somerville, MA and Oakland, CA: Political Research Associates and Women of Color Resource Center. 
Hardisty, Jean V. 2008b. Marriage as a Cure for Poverty? Social Science through a 'Family Values'Lens. Somerville, MA and Oakland, CA: Political Research Associates and Women of Color Resource Center.

Hawkins, Allan J., and Theadora Ooms. 2010. What Works in Marriage and Relationship Education? A Review of Lessons Learned with a Focus on Low-Income Couples. Littleton, CO: National Healthy Marriage Resource Center.

Healthy Marriage - Federal Grants 2011. November 2011. Youth Today, p. 24.

Heath, Melanie. 2012. One Marriage under God: The Campaign to Promote Marriage in America. New York, NY: New York University Press.

Heath, Melanie. 2009. "State of Our Unions: Marriage Promotion and the Contested Power of Heterosexuality." Gender \& Society 23: 27-48.

Hickman, Laura J, Lisa A. Jaycox, and Jessica Aronoff. 2004. “Dating Violence Among Adolescents: Prevalence, Gender Distribution and Prevention Program Effectiveness.” Trauma Violence Abuse 5: 123-142.

Hudson Institute. 1999. A Futurist Perspective: 1999 Annual Report. Indianapolis, IN: Hudson Institute.

Jouriles, Ernest N., Cora Platt, and Renee McDonald. 2009. "Violence in Adolescent Dating Relationships." The Prevention Researcher 16: 3-7.

Katz, Jackson. 2006. The Macho Paradox: Why Some Men Hurt Women and How All Men Can Help. Naperville, IL: Sourcebooks.

Kimmel, Michael. 2002. "Gender, Class, and Terrorism." The Chronicle of Higher Education, February 8, B11-12. 
Kurz, Demie. 1997. "Violence Against Women or Family Violence? Current Debates and Future Directions.” In Gender Violence: Interdisciplinary Perspectives, eds. Laura L. O’Toole, Jessica R. Schiffman, and Margie L. Kiter Edwards, 443-453.

Lyon, Eleanor, and Menard, Anne. 2008. Informing and Enhancing Response to Domestic Violence Within Federally Funded Healthy Marriage Projects: A Summary Report Prepared for the Annie E. Casey Foundation. Harrisburg, PA: National Resource Center on Domestic Violence.

Lyon, Eleanor. 2002. Welfare and Domestic Violence Against Women: Lessons From Research. Harrisburg, PA: National Resource Center on Domestic Violence.

Massachusetts Department of Education. 2011. 2011 Massachusetts Youth Risk Behavior Survey. http://www.doe.mass.edu/cnp/hprograms/yrbs/2011questions.pdf (May 16, 2013).

Menard, Anne and Oliver Williams. 2005. “It's Not Healthy If It's Not Safe: Responding to Domestic Violence Issues Within Healthy Marriage Programs. Presented at Association for Public Policy Analysis and Management (APPAM), Washington, DC (updated May 2006).

Merry, Sally E. 2009. Gender Violence: A Cultural Perspective. West Sussex, UK: WileyBlackwell.

Middle Class Tax Relief and Job Creation Act. 2012. U.S. Code. Vol. 42, sec. 603.

Mink, Gwendolyn. 2002. 'From Welfare to Wedlock: Marriage Promotion and Poor Mothers' Inequality. Review of Public Vows: A History of Marriage and the Nation by Nancy F. Cott." In The Good Society 11; 68-73. 
Molidor, Christian, and Richard M. Tolman. 1998. "Gender and Contextual Factors in Adolescent Dating Violence.” Violence Against Women 4(2): 180-194.

Mulford, Carrie F., and Blachman-Demner, Dara R. 2013. "Teen Dating Violence: Building a Research Program Through Collaborative Insights," Violence Against Women 19(6): 756770.

Mulford, Carrie, and Peggy C. Giordano. 2008. "Teen Dating Violence: A Closer Look at Adolescent Romantic Relationships.” NIJ (National Institute of Justice) Journal 261: 3440.

National Institute for Justice. 2011. Violence and Victimization Research Division's Compendium of Research on Violence Against Women, 1993-2011, Category I: Teen Dating Violence. Washington, DC: National Institute for Justice. https://www.ncjrs.gov/pdffiles1/nij/223572/223572-i.pdf (May 16, 2013).

National Law Center on Homelessness and Poverty. 2009. Shortchanging Survivors: The Family Violence Option for TANF Benefits. Washington D.C.: National Law Center on Homelessness and Poverty. http://www.nlchp.org/content/pubs/Shortchanging_Survivors_Report_20092.pdf (August 23, 2013).

National Resource Center on Domestic Violence. 2011. VAWNET Special Collection: Building Collaborations between Healthy Marriage And Relationship Education and Domestic Violence Programs. Harrisburg, PA: National Resource Center on Domestic Violence. National Youth Violence Prevention Resource Center. 2001. Facts for Teens: Teen Dating

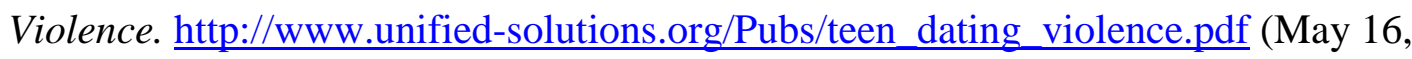
2013). 
NOW Legal Defense and Education Fund. 2004. Class Complaint of Sex Discrimination in Violation of Title IX. Submitted to the U.S. Department of Health and Human Services.

February 4. http://old.povertylaw.org/poverty-law-library/case/55500/55535/55535a.pdf (May 16, 2013).

Offenhauer, Priscilla, and Alice Buchalter. 2011. Teen Dating Violence: A Literature Review and Annotated Bibliography. Washington, DC: United States Department of Justice.

O’Leary, K. Daniel and Amy M. Smith Slep. 2012. "Prevention of Partner Violence by Focusing on Behaviors of Both Young Males and Females.” Prevention Science 13(4): 329-339.

Olson, Sarah. 2005. "Marriage Promotion, Reproductive Injustice and the War Against Poor Women of Color.” Dollars and Sense, January-February, 14.

Ooms, Theadora, Jacqueline Boggess, J., Anne Menard, Mary Myrick, Paula Roberts, Jack Tweedie, and Pamela Wilson. 2006. Building Bridges Between Healthy Marriage, Responsible Fatherhood, and Domestic Violence Programs: A Preliminary Guide. Washington, DC: National Center for State Legislatures and Center for Law and Social Policy.

Perlstein, Daniel. 1998. "Saying the Unsaid: Girl Killing and the Curriculum.” Journal of Curriculum and Supervision 14: 88-104.

Personal Responsibility and Work Opportunity Reconciliation Act. 1996. Statutes at Large. Vol. 110, sec. 2105 .

Personal Responsibility, Work and Family Promotion Act. 2003. H.R. 4, $108^{\text {th }}$ Congress, $1^{\text {st }}$ Session, $§ 103$.

Rambo, Kirsten S. 2009. Trivial Complaints: The Role of Privacy in Domestic Violence Law and Activism in the U.S. New York: Columbia University Press. 
Reed, Elizabeth, Jay G. Silverman, Anita Raj, Michele R. Decker, and Elizabeth Miller. 2011. "Male Perpetration of Teen Dating Violence: Associations with Neighborhood Violence Involvement, Gender Attitudes, and Perceived Peer and Neighborhood Norms.” Journal of Urban Health 88(2): 226-229.

Reed, Elizabeth, Anita Raj, Elizabeth Miller, and Jay G. Silverman. 2010. 'Losing the 'Gender' in Gender-Based Violence: The Missteps of Research on Dating and Intimate Partner Violence." Violence Against Women 16: 348-354.

Rothman, Emily F. 2012. “Assessing the Prevalence of Dating Violence Using National and State YRBS Data from1999-2009: What We've Learned, and How We Might Improve the YRBS Question Going Forward.” Presentation, National Conference on Health and Domestic Violence, San Francisco, CA. March 29-31.

Römkens, Renée. 2013. "Reflections on Domestic Violence as Gender-Based Violence in European Legal Development." In Family Ambiguity and Domestic Violence in Asia. Concept, Law and Process, eds. Maznah Mohamad and Saskia E. Wieringa. Brighton/Portland/Toronto: Sussex Academic Press, 192-209.

Roulet, Marguerite. 2009. Fatherhood Programs and Health Marriage Funding. Madison, WI: Center for Family and Policy Practice.

Schechter, Susan. 1982. Women and Male Violence: The Visions and Struggles of the Battered Women's Movement. Boston, MA: South End Press.

Sears, Heather A, Sandra E. Byers, John J. Whelan, and Marcelle Saint-Pierre. 2006. "If It Hurts You, Then it is Not a Joke: Adolescents' Ideas About Girls and Boys Use and Experience of Abusive Behavior in Dating Relationships.” Journal of Interpersonal Violence 21(9): 1119-1207. 
Silverman, Jay G., Anita Raj, and Karen Clements. 2004. "Dating Violence and Associated Sexual Risk and Pregnancy Among Adolescent Girls in the United States.” Pediatrics 114(2): 220-225.

Silverman, Jay G., Anita Raj, Lorelei A. Mucci, and Jeanne E. Hathaway. 2001. "Dating Violence Against Adolescent Girls and Associated Substance Abuse, Unhealthy Weight Control, Sexual Risk Behavior, Pregnancy, and Suicidality." Journal of the American Medical Association 286(5): 572-579.

Stein, Nan D., and Gena Hong. 2012. "Violence in Adolescent Dating Relationships: In Danger of Losing Its Gendered and Legal Reality.” Paper presented at the Annual Meeting of the Law and Society Association, Honolulu, HI. June 6.

Stein, Nan D., and Kelly A. Mennemeier. 2011. Addressing the Gendered Dimensions of Harassment and Bullying: What Domestic and Sexual Violence Advocates Need to Know. Harrisburg, PA: The National Resource center on Domestic Violence and The National Sexual Violence Resource Center. http://www.vawnet.org/Assoc_Files_VAWnet/CIB_HarassmentBullying.pdf (May 16, 2013).

Stein, Nan D. 2011. Sexual Harassment in Schools: Concerns, New Directions and Strategies for Prevention. Wellesley, MA: Wellesley Centers for Women.

Stein, Nan. 2003. "Bullying or Harassment? The Missing Discourse of Rights in an Era of Zero Tolerance.” Arizona Law Review 45(3): 783-799.

Stein, Nan. 1995. "Sexual Harassment in K-12 Schools: The Public Performance of Gendered Violence." The Harvard Educational Review 65(2): 145-162.

Steinem, Gloria. 1999. “Supremacy Crimes.” Ms. 9(5): 44-47. 
Straus, Murray A. 2011. “Gender Symmetry and Mutuality in Perpetration of Clinical-Level Partner Violence: Empirical Evidence and Implications for Prevention and Treatment.” Aggression and Violent Behavior 13: 141-140.

Straus, Murray A. 2008. "Dominance and Symmetry in Partner Violence by Male and Female University Students in 32 Nations.” Children and Youth Services Review 30: 252-275.

Straus, Murray A. 2007. "Processes Explaining the Concealment and Distortion of Evidence on Gender Symmetry in Partner Violence.” European Journal Criminal Policy Research 13: 227-232.

Straus, Murray A. 2005. "Women's Violence Toward Men is a Serious Social Problem.” In Current Controversies on Family Violence. 6 ed., eds. Donileen R. Loseke, Richard J. Gelles \& Mary M. Cavanaugh. Newbury Park: Sage Publications, 55-77.

Straus, Murray A., Sherry L. Hamby, Susan Boney-McCoy, and David B. Sugerman. 1996. “The Revised Conflict Tactics Scale (CTS2).” Family Issues 17: 283-316.

Straus, Murray 1979. "Measuring Intrafamily Conflict and Violence." Journal of Marriage and the Family 41: 13-29.

Taylor, Bruce G., Nan D. Stein, Elizabeth A. Mumford, and Daniel Woods. 2013. "Shifting Boundaries: An Experimental Evaluation of a Dating Violence Prevention Program in Middle Schools.” Prevention Science 14(1): 64-76.

Taylor, Bruce, Nan Stein, and Frances Burden. 2010a. "The Effects of Gender Violence/Harassment Prevention Programming in Middle Schools: A Randomized Experimental Evaluation." Violence and Victims 25(2): 202-223. 
Taylor, Bruce, Nan Stein, and Frances Burden. 2010b. "Exploring Gender Differences in Dating Violence/Harassment Prevention Programming in Middle Schools: Results from a Randomized Experiment." Journal of Experimental Criminology 6(4): 419-445.

Tharp, Andra Teten. 2012. "Dating Matters ${ }^{\mathrm{TM}}$ : The Next Generation of Teen Dating Violence Prevention.” Prevention Science 13(4): 398-401.

Tolman, Deborah, Renée Spencer, Myra Rosen-Reynoso, and Michele Porche. 2003. “Sowing the Seeds of Violence in Heterosexual Relationships: Early Adolescents Narrate Compulsory Heterosexuality.” Journal of Social Issues 59(1): 159-178.

Tolman, Richard M., \& Rosen, Daniel. 2001. "Domestic Violence in the Lives of Women Receiving Welfare.” Violence Against Women 7(2): 141-158.

United States Agency for International Development. 2012. United States Strategy to Prevent and Respond to Gender-Based Violence Globally. Washington, DC: United States Agency for International Development.

United States Department of Education Office for Civil Rights. 2010. Dear Colleague Letter: Harassment and Bullying. From the Office of the Assistant Secretary. October 26. http://www2.ed.gov/about/offices/list/ocr/letters/colleague-201010.pdf (May 16, 2013). United States Department of Health and Human Services, Administration for Children and Families, Office of Family Assistance. 2012. School of Thought: Healthy Marriage and Relationship Education Matters to Our Youth. Washington, DC: United States Department of Health and Human Services.

United States House of Representatives, Committee on Government Reform, Minority Staff, Special Investigations Division. 2004. The Content of Federally Funded Abstinence-Only 
Education Programs: A Report Prepared for Henry Waxman. December.

http://www.apha.org/apha/PDFs/HIV/The_Waxman_Report.pdf (May 16, 2013).

United States v. Morrison. 2000. 529 U.S. 598.

VAWnet.org. 2011. Special Collection: Building Collaborations Between Healthy Marriage \& Relationship Education and Domestic Violence Programs. Littleton, CO and Harrisburg, PA: National Healthy Marriage Resource Center and the National Resource Center on Domestic Violence. http://www.vawnet.org/special-collections/DVHealthyMarriage.php (May 16, 2013).

VAWnet.org. 2008. Promoting Safety Together: Domestic Violence and Healthy Marriage Programs - A Capitol Hill Briefing Seminar by the National Healthy Marriage Resource Center and the National Resource Center on Domestic Violence. July 18. http://www.vawnet.org/summary.php?doc_id=2868\&find_type=web_desc_GC (May 16, 2013).

Youth Risk Behavior Surveillance Survey. http://www.cdc.gov/healthyyouth/yrbs/index.htm (May 16, 2013). 